\title{
Article
}

\section{In Vitro and In Silico Study of Analogs of Plant Product Plastoquinone to Be Effective in Colorectal Cancer Treatment}

\author{
Halilibrahim Ciftci ${ }^{1,2,3}{ }^{\circ}$, Belgin Sever ${ }^{2,4}{ }^{\oplus}$, Firdevs Ocak ${ }^{5}$, Nilüfer Bayrak ${ }^{6}$, Mahmut Yıldız $^{7}$, Hatice Yıldırım $^{6}$, \\ Hasan DeMirci ${ }^{3}{ }^{\mathbb{D}}$, Hiroshi Tateishi ${ }^{2}$, Masami Otsuka ${ }^{1,2}$, Mikako Fujita ${ }^{2, *}$ and Amaç Fatih TuYuN ${ }^{8, *}$
}

check for

updates

Citation: Ciftci, H.; Sever, B.; Ocak, F.; Bayrak, N.; Yıldız, M.; Yıldırım, H.; DeMirci, H.; Tateishi, H.; Otsuka, M.; Fujita, M.; et al. In Vitro and In Silico Study of Analogs of Plant Product Plastoquinone to Be Effective in Colorectal Cancer Treatment. Molecules 2022, 27, 693. https:// doi.org/10.3390/molecules27030693

Academic Editor: Bruno Botta

Received: 13 December 2021

Accepted: 18 January 2022

Published: 21 January 2022

Publisher's Note: MDPI stays neutral with regard to jurisdictional claims in published maps and institutional affiliations.

Copyright: (C) 2022 by the authors. Licensee MDPI, Basel, Switzerland. This article is an open access article distributed under the terms and conditions of the Creative Commons Attribution (CC BY) license (https:// creativecommons.org/licenses/by/ $4.0 /)$.
1 Department of Drug Discovery, Science Farm Ltd., Kumamoto 862-0976, Japan; hiciftci@kumamoto-u.ac.jp (H.C.); motsuka@gpo.kumamoto-u.ac.jp (M.O.)

2 Medicinal and Biological Chemistry Science Farm Joint Research Laboratory, Faculty of Life Sciences, Kumamoto University, Kumamoto 862-0973, Japan; belginsever@anadolu.edu.tr (B.S.); htateishi@kumamoto-u.ac.jp (H.T.)

3 Department of Molecular Biology and Genetics, Koc University, Istanbul 34450, Turkey; hdemirci@ku.edu.tr 4 Department of Pharmaceutical Chemistry, Faculty of Pharmacy, Anadolu University, Eskisehir 26470, Turkey $5 \quad$ Faculty of Medicine, Kocaeli University, Kocaeli 41001, Turkey; 200601195@kocaeli.edu.tr

6 Department of Chemistry, Faculty of Engineering, Istanbul University-Cerrahpasa, Istanbul 34320, Turkey; nbayrak@istanbul.edu.tr (N.B.); hyildirim@istanbul.edu.tr (H.Y.)

7 Chemistry Department, Gebze Technical University, Kocaeli 41400, Turkey; yildizm@gtu.edu.tr

8 Department of Chemistry, Faculty of Science, Istanbul University, Istanbul 34126, Turkey

* Correspondence: mfujita@kumamoto-u.ac.jp (M.F.); aftuyun@istanbul.edu.tr (A.F.T.); Tel.: +81-96-371-4622 (M.F.); +90-212-4400000 (A.F.T.)

\begin{abstract}
Plants have paved the way for the attainment of molecules with a wide-range of biological activities. However, plant products occasionally show low biological activities and/or poor pharmacokinetic properties. In that case, development of their derivatives as drugs from the plant world has been actively performed. As plant products, plastoquinones (PQs) have been of high importance in anticancer drug design and discovery; we have previously evaluated and reported the potential cytotoxic effects of a series of PQ analogs. Among these analogs, PQ2, PQ3 and PQ10 were selected for National Cancer Institute (NCI) for in vitro screening of anticancer activity against a wide range of cancer cell lines. The apparent superior anticancer potency of PQ2 on the HCT-116 colorectal cancer cell line than that of PQ3 and PQ10 compared to other tested cell lines has encouraged us to perform further mechanistic studies to enlighten the mode of anti-colorectal cancer action of PQ2. For this purpose, its apoptotic effects on the HCT-116 cell line, DNA binding capacity and several crucial pharmacokinetic properties were investigated. Initially, MTT assay was conducted for PQ2 at different concentrations against HCT-116 cells. Results indicated that PQ2 exhibited significant cytotoxicity in HCT-116 cells with an $\mathrm{IC}_{50}$ value of $4.97 \pm 1.93 \mu \mathrm{M}$ compared to cisplatin $\left(\mathrm{IC}_{50}=26.65 \pm 7.85 \mu \mathrm{M}\right)$. Moreover, apoptotic effects of PQ2 on HCT-116 cells were investigated by the annexin V/ethidium homodimer III staining method and PQ2 significantly induced apoptosis in HCT-116 cells compared to cisplatin. Based on the potent DNA cleavage capacity of PQ2, molecular docking studies were conducted in the minor groove of the double helix of DNA and PQ2 presented a key hydrogen bonding through its methoxy moiety. Overall, both in vitro and in silico studies indicated that effective, orally bioavailable drug-like PQ2 attracted attention for colorectal cancer treatment. The most important point to emerge from this study is that appropriate derivatization of a plant product leads to unique biologically active compounds.
\end{abstract}

Keywords: plastoquinones; colorectal cancer; cytotoxicity; apoptosis; DNA cleavage; molecular docking; pharmacokinetic properties

\section{Introduction}

Chemotherapy is the main cancer treatment, whereas the drugs used in this treatment are no longer effective because of the drug resistance in cancer cell lines and / or undesirable 
side effects due to the lack of selectivity for cancer vs. normal cell lines [1]. For this reason, in order to cope with this disease, the development of new drug candidates with new therapeutic strategies based on natural products is urgently needed [2,3]. Many of the second metabolites are chemotherapeutically useful natural products which are the thriving source of anticancer drug discovery. For example, many compounds from nature demonstrate potent structures and remarkable activities, in particular anticancer properties [4-6]. Structure-based design from bioactive natural products is one of the most promising and fundamental approaches to generate novel selective biologically active molecules with favorable pharmacological properties $[7,8]$. For clinical use, most approved small anticancer molecules (around 83\%), 113 of the total 136 molecules, are generated from natural products or inspired from natural products [9]. The importance of natural products would be that not only they can act on maximum efficacy in most cases and quench adverse effects, but they also are capable of multi-targeting [10].

Over the last years or so, the use of 1,4-quinone, an important source of natural products, has enabled the design of efficient and active molecules with improved pharmacological properties in the search of new molecules with cytotoxic activity [11-16]. The 1,4-quinone and 1,4-naphthoquinone moieties are well-represented in bioactive natural structures and their anticancer effects, including anti-colorectal cancer properties, have been documented in several studies. Among these compounds, embelin (2,5-dihydroxy-3undecyl-1,4-benzoquinone) (Figure 1) is isolated from the fruit of the herbal plant Embelia ribes and its antitumor effects have long been known. Embelin was shown to lead a significant decrease in tumor growth in mice, which were treated with the mixture of embelin and murine B16-F1 melanoma cells or LS174T human colon carcinoma cells [17]. Thymoquinone (2-isopropyl-5-methyl-1,4-benzoquinone) (Figure 1), one of the most important molecules isolated from natural product Nigella Sativa L., displayed an antiproliferative activity towards a range of cancer cell lines, including colorectal cancer cells [18,19]. Juglone (5-hydroxy-1,4-napthoquinone) (Figure 1), a natural component isolated from walnut trees, has been reported to inhibit tumor proliferation and metastasis and induce apoptosis in different types of cancer such as colorectal carcinoma [20-22]. Lawsone (2-hydroxy1,4-naphthoquinone) (Figure 1) and plumbagin (5-hydroxy-2-methyl-1,4-napthoquinone) (Figure 1) are other 1,4-naphthoquinone-based natural products with potent anti-colorectal cancer effects [23]. Further to that, the structure-activity relationship elucidation paves the way to the foundation for lead optimization.<smiles>CCCCCCCCCCCC1=C(O)C(=O)CC(O)C1=O</smiles><smiles>CC1=CC(=O)C(C(C)C)=CC1=O</smiles><smiles>O=C1C=CC(=O)c2c(O)cccc21</smiles><smiles>O=C1C=C(O)C(=O)c2ccccc21</smiles><smiles>CC1=CC(=O)c2c(O)cccc2C1=O</smiles>

Figure 1. Quinone-based plant products with anti-colorectal cancer properties.

Regarding uses of important drugs for the treatment of cancer, mitomycin C, mitoxantrone, and doxorubicin draw attention and contain the 1,4-quinone moiety (Figure 2). After realizing the prominent anticancer activity of those structures, we created more using nature as a model, namely plastoquinones (PQ) discovered by Barr for electron transfer 
in photosynthesis in 1946 [24] containing both 2,3-dimethyl-1,4-benzoquinone structure and a side chain of nine isoprenyl group as PQ-A or PQ-9 [25] or shorter side chain such as PQ-3 with three isoprenyl side units, as shown in Figure 3 [26]. Studying common pharmacophoric features of $\mathbf{P Q}$ analogs has revealed that the presence of three main features, as shown in Figure 3, are important. These structures are (1) 2,3-dimethyl-1,4-benzoquinone as a main core structure, (2) aryl amines or thiols with different substituents, and (3) the presence of halogen (bromine and chlorine) or hydrogen atom since different combinations of these three main moieties affect the biological potential of molecules.<smiles></smiles><smiles>COc1cccc2c1C(=O)c1c(O)c3c(c(O)c1C2=O)C[C@@](O)(C(=O)CO)C[C@@H]3O[C@H]1C[C@H](N)[C@H](O)[C@H](C)O1</smiles>

Doxorubicin

Figure 2. Mitomycin C, mitoxantrone, and doxorubicin, potential anticancer drugs the containing 1,4-quinone moiety.

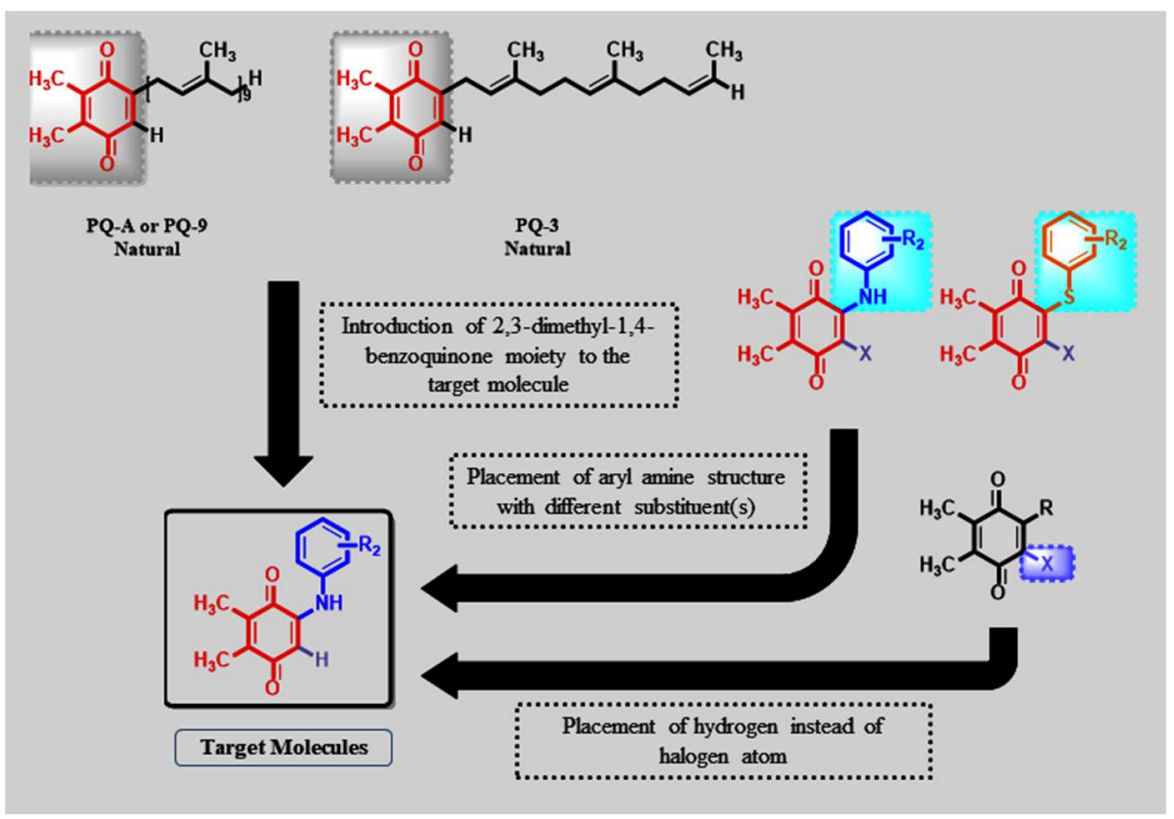

Figure 3. Design concept of $\mathbf{P Q}$ analogs based on our previous studies.

In the period of 2017-2021, with the purpose of identification of new lead molecules based on natural products that specifically target leukemia cancer cell lines, we mainly 
focused on the quinones namely $\mathbf{P Q}$ analogs containing two important moieties (2,3dimethyl-1,4-benzoquinone and primary/secondary amines or thiols) [27-31], encouraged by our previous results and experiences with 1,4-quinones [32-34]. Considering our previous findings that demonstrated greater anticancer activity by the introduction of an alkoxy group with a short alkyl chain [28,29], we also evaluated the effect of weak (methyl) or strong (methoxy) electron-donating group(s) to the $\mathbf{P Q}$ structure [27]. We recently reported the $\mathbf{P Q}$ analogs with aryl amines containing alkoxy substituent(s) as highly effective agents against two human cancer cell lines (K562 and Jurkat cells). Three PQ analogs (PQ2, PQ3, and PQ10) exhibited remarkable cytotoxic activities along with low toxicity towards the human peripheral blood mononuclear cell line (PBMC) (healthy), as shown in Table 1. Figure 4 illustrates the structures of selected $\mathbf{P Q}$ analogs. Moreover, the study showed that the selected $\mathbf{P Q}$ analog (PQ2) induced apoptosis in vitro in human chronic myelogenous leukemia cell lines exhibiting no toxicity in PBMC. In addition, the BCR-ABL1 mediated ERK pathway was clearly induced by PQ2. This analog (PQ2) enhanced the DNA cleaving capability with an iron (II) complex system [29].

Table 1. The cytotoxic effects of PQ2, PQ3, and PQ10 on K562, Jurkat, MT-2 and PBMC cells compared to imatinib.

\begin{tabular}{|c|c|c|c|c|c|c|c|c|}
\hline \multirow{2}{*}{ ID } & \multicolumn{4}{|c|}{ Substitution Groups } & \multicolumn{4}{|c|}{ Cell Type $\left(\mathrm{IC}_{50}, \mu \mathrm{M}\right)$} \\
\hline & $\mathbf{R}_{\mathbf{1}}$ & $\mathbf{R}_{2}$ & $\mathbf{R}_{3}$ & $\mathbf{R}_{4}$ & $\mathrm{~K} 562^{\mathrm{a}}$ & Jurkat $^{a}$ & MT-2 $^{\text {a }}$ & PBMC $^{a}$ \\
\hline PQ2 & $\mathrm{H}$ & $\mathrm{OCH}_{3}$ & $\mathrm{H}$ & $\mathrm{H}$ & $6.40 \pm 1.73$ & $7.72 \pm 1.49$ & $>100$ & $>300$ \\
\hline PQ3 & $\mathrm{H}$ & $\mathrm{H}$ & $\mathrm{OCH}_{3}$ & $\mathrm{H}$ & $9.66 \pm 2.31$ & $22.75 \pm 1.93$ & $53.96 \pm 3.81$ & $72.68 \pm 6.51$ \\
\hline PQ10 & $\mathrm{H}$ & $\mathrm{OCH}_{3}$ & $\mathrm{OCH}_{3}$ & $\mathrm{H}$ & $8.91 \pm 1.26$ & $14.47 \pm 1.35$ & $35.79 \pm 0.89$ & $69.35 \pm 7.12$ \\
\hline \multicolumn{5}{|c|}{ Imatinib b } & $7.47 \pm 2.22$ & $9.49 \pm 2.46$ & $22.09 \pm 1.76$ & $39.81 \pm 4.38$ \\
\hline
\end{tabular}

${ }^{a}$ Cell lines include chronic myelogenous leukemia (K562), other leukemias (Jurkat and MT-2), and peripheral blood mononuclear cells (PBMC). ${ }^{\text {b }}$ Used as a reference.<smiles>COc1cccc(NC2=CC(=O)C(C)=C(C)C2=O)c1</smiles>

PQ2<smiles>COc1ccc(NC2=CC(=O)C(C)=C(C)C2=O)cc1</smiles>

PQ3<smiles>COc1ccc(NC2=CC(=O)C(C)=C(C)C2=O)cc1OC</smiles>

PQ10

Figure 4. Structures of selected PQ analogs involved in the exploration.

In this study, three PQ analogs were evaluated in in vitro screening of anticancer activities against a panel of 60 cancer cell lines at $10 \mu \mathrm{M}$ concentration. Based on these encouraging results, in the search for new lead molecules as antiproliferative agents, we focused on the discovery of the selected PQ analogs for their antiproliferative activity against the HCT-116 colorectal cancer cell line. Correspondingly, apoptotic effects, DNA binding potential and some essential absorption, distribution, metabolism and excretion (ADME) properties of the most effective anti-colorectal cancer agent were further investigated.

\section{Results}

\subsection{Biological Activity}

2.1.1. In Vitro Screening of Antiproliferative Activity at One Dose

In order to study the full cytotoxic profile of three $\mathbf{P Q}$ analogs, the antiproliferative in vitro assay at a single dose of concentration $(10 \mu \mathrm{M})$ was carried out by the National Cancer Institute (NCI) of Bethesda within the Developmental Therapeutics Program (DTP) against the panel of sixty human cancer cell lines, which includes nine tumor subpanels, namely: leukemia, non-small cell lung cancer (NSCLC), colorectal cancer, central nervous system (CNS) cancer, melanoma, ovarian, renal, prostate and breast cancer cell lines [35]. 
Herein, three PQ analogs namely PQ2, PQ3, and PQ10 were selected by the NCI for in vitro disease oriented human cells screening panel assay. The cell growth/viability of PQ2, PQ3, and PQ10 was screened using a sulphorhodamine B (SRB) test, thus both in vitro growth inhibition and lethality were determined based on the specified values, which were between 0 and 100 and less than 0 , respectively.

The mean growth percent-growth percent of $\mathbf{P Q}$ analogs against for each cell line were depicted as bars in the one-dose mean graphs (Figures 5-7 and Table 2). In general, PQ3 and PQ10 showed less inhibitory effects than PQ2 on the tested cancer cell lines. PQ3 presented the most significant inhibition against the MDA-MB-435 melanoma cell line with $92.20 \%$ inhibition percent followed by the OVCAR-3 ovarian cancer cell line $(90.06 \%)$ (Table 2). Both analogs (PQ2 and PQ3) showed good inhibitory profiles in MDA-MB-435 and OVCAR-3 cell lines. However, PQ10 displayed the most significant inhibitory effects on MDA-MB- 468 breast cancer cells with an inhibition percent of $81.85 \%$ followed by CCRF-CEM leukemia (72\%) and OVCAR-3 ovarian cancer (71.28\%) cell lines (Table 2). Among these analogs, PQ2 was identified as the most effective antiproliferative agent with its inhibitory potency against different cancer cell lines with notable inhibition percent values in particular against HCT-116 colorectal cancer (89.46\%), MDA-MB-435 melanoma (92.75\%), OVCAR-3 ovarian cancer $(99.71 \%)$ cell lines along with broad spectrum potent inhibitory effects on all the leukemia cell lines (Table 2). PQ2 exhibited excellent to moderate antiproliferative activity to some leukemia cell lines supporting the previous report by our group regarding anti-leukemic effects of PQ2 on $\mathrm{K} 562$ and Jurkat cells with $\mathrm{IC}_{50}$ values of $6.40 \pm 1.73 \mu \mathrm{M}$ and $7.72 \pm 1.49 \mu \mathrm{M}$, respectively [30]. Previously, PQ2 was also found to exert no cytotoxicity on healthy cell lines (PBMC) (>300 $\mu \mathrm{M})$.

Table 2. Antiproliferative activity data as per single-dose assay at $10 \mu \mathrm{M}$ concentration as cell growth percent of $\mathbf{P Q}$ analogs. All experiments were repeated one time.

\begin{tabular}{|c|c|c|c|}
\hline \multirow{3}{*}{ Panel/Cancer Cell Line } & \multicolumn{3}{|c|}{ Compounds } \\
\hline & PQ2 & PQ3 & PQ10 \\
\hline & \multicolumn{3}{|c|}{ Growth Percent } \\
\hline \multicolumn{4}{|l|}{ Leukemia } \\
\hline CCRF-CEM & 15.84 & 70.07 & 28.00 \\
\hline HL-60(TB) & 3.49 & 80.23 & 43.99 \\
\hline K-562 & 12.54 & 66.58 & 86.47 \\
\hline MOLT-4 & 17.89 & 75.57 & 45.57 \\
\hline RPMI-8226 & 17.52 & 73.34 & 73.88 \\
\hline SR & 23.16 & 82.29 & 65.36 \\
\hline \multicolumn{4}{|l|}{ NSCLC } \\
\hline A549/ATCC & 101.36 & 97.30 & 102.53 \\
\hline EKVX & 36.72 & 78.84 & 80.02 \\
\hline HOP-62 & 105.69 & 99.66 & 112.71 \\
\hline HOP-92 & 104.31 & 171.92 & 136.73 \\
\hline NCI-H226 & 97.00 & 97.24 & 109.09 \\
\hline NCI-H23 & $\mathrm{ND}^{*}$ & ND * & 69.62 \\
\hline NCI-H322M & 101.88 & 103.08 & 102.13 \\
\hline NCI-H460 & 100.51 & 99.63 & 100.07 \\
\hline NCI-H522 & 49.81 & 82.47 & 86.90 \\
\hline \multicolumn{4}{|l|}{ Colorectal Cancer } \\
\hline COLO 205 & 103.02 & 106.66 & 112.41 \\
\hline HCC-2998 & $\mathrm{ND} *$ & ND* & 113.67 \\
\hline HCT-116 & 10.54 & 80.60 & 92.46 \\
\hline HCТ-15 & 91.87 & 89.04 & 95.39 \\
\hline HT29 & 98.29 & 109.10 & 105.03 \\
\hline KM12 & 98.44 & 101.37 & 101.36 \\
\hline SW-620 & 101.81 & 101.18 & 102.32 \\
\hline
\end{tabular}


Table 2. Cont.

\begin{tabular}{|c|c|c|c|}
\hline \multirow{3}{*}{ Panel/Cancer Cell Line } & \multicolumn{3}{|c|}{ Compounds } \\
\hline & PQ2 & PQ3 & PQ10 \\
\hline & \multicolumn{3}{|c|}{ Growth Percent } \\
\hline \multicolumn{4}{|l|}{ CNS Cancer } \\
\hline SF-268 & 74.53 & 100.81 & 107.49 \\
\hline SF-295 & 105.11 & 104.94 & 108.44 \\
\hline SF-539 & 21.69 & 104.69 & 117.66 \\
\hline SNB-19 & 97.72 & 99.17 & 101.23 \\
\hline SNB-75 & 99.78 & 123.25 & 110.24 \\
\hline $\mathrm{U} 251$ & 95.10 & 92.04 & 100.71 \\
\hline \multicolumn{4}{|l|}{ Melanoma } \\
\hline LOX IMVI & ND * & $\mathrm{ND} *$ & 70.80 \\
\hline MALME-3M & 101.18 & 89.92 & 102.29 \\
\hline M14 & 97.05 & 95.56 & 101.40 \\
\hline MDA-MB-435 & 7.25 & 7.80 & 103.13 \\
\hline SK-MEL-2 & 83.57 & 81.83 & 95.65 \\
\hline SK-MEL-28 & 96.53 & 99.39 & 110.98 \\
\hline SK-MEL-5 & $\mathrm{ND}^{*}$ & $\mathrm{ND} *$ & 97.50 \\
\hline UACC-257 & 54.67 & 45.42 & 87.07 \\
\hline UACC-62 & 91.77 & 95.37 & 97.60 \\
\hline \multicolumn{4}{|l|}{ Ovarian Cancer } \\
\hline IGROV1 & 39.99 & 89.25 & 104.41 \\
\hline OVCAR-3 & 0.29 & 9.94 & 28.72 \\
\hline OVCAR-4 & -1.68 & 43.81 & 42.19 \\
\hline OVCAR-5 & 100.60 & 109.36 & 107.95 \\
\hline OVCAR-8 & 16.95 & 79.12 & 89.21 \\
\hline NCI/ADR-RES & $\mathrm{ND}^{*}$ & $\mathrm{ND}^{*}$ & 80.54 \\
\hline SK-OV-3 & $\mathrm{ND}^{*}$ & $\mathrm{ND} *$ & ND * \\
\hline \multicolumn{4}{|l|}{ Renal Cancer } \\
\hline $786-0$ & 95.76 & 90.51 & 105.71 \\
\hline A498 & 67.18 & 84.44 & 85.07 \\
\hline $\mathrm{ACHN}$ & 70.90 & 96.11 & 96.60 \\
\hline CAKI-1 & 93.02 & 93.46 & 104.67 \\
\hline RXF 393 & 55.80 & 101.91 & 114.84 \\
\hline SN12C & 80.52 & 86.43 & 94.65 \\
\hline TK-10 & 135.29 & 156.13 & 158.01 \\
\hline UO-31 & 86.04 & 81.15 & 98.44 \\
\hline \multicolumn{4}{|l|}{ Prostate Cancer } \\
\hline PC-3 & 36.32 & 71.45 & 81.05 \\
\hline DU-145 & 113.12 & 105.22 & 112.19 \\
\hline \multicolumn{4}{|l|}{ Breast Cancer } \\
\hline MCF7 & 64.11 & 71.87 & 88.94 \\
\hline MDA-MB-231/ATCC & 41.39 & 83.80 & 88.36 \\
\hline HS 578T & 112.09 & 109.96 & 110.28 \\
\hline BT-549 & 127.05 & 118.89 & 123.57 \\
\hline $\mathrm{T}-47 \mathrm{D}$ & 47.75 & 67.51 & 62.22 \\
\hline MDA-MB-468 & 25.85 & 56.98 & 18.15 \\
\hline
\end{tabular}

* "ND" means not determined. 


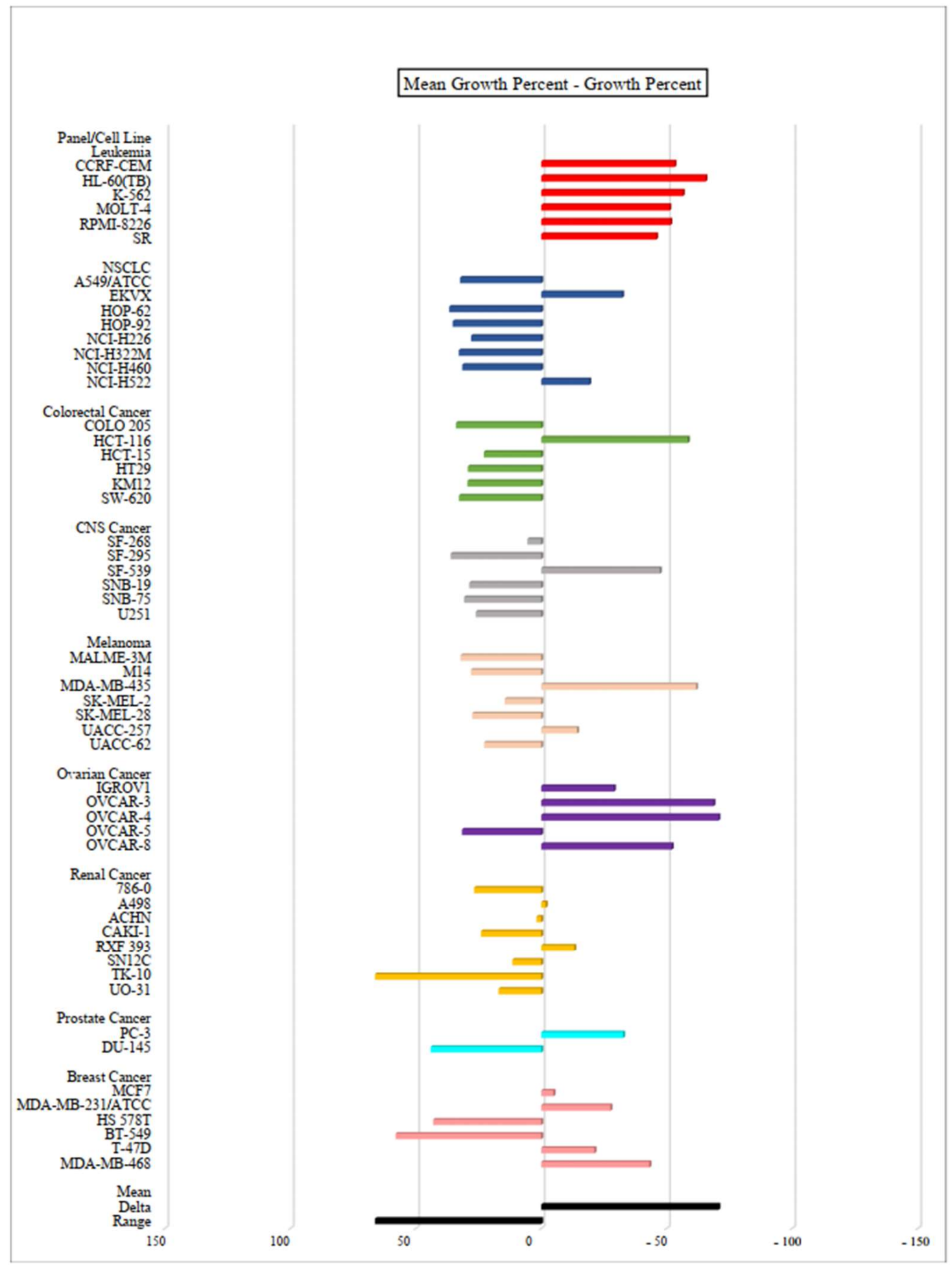

Figure 5. One-dose $(10 \mu \mathrm{M})$ mean graph of PQ2 against different cancer cell lines. All experiments were repeated one time. 


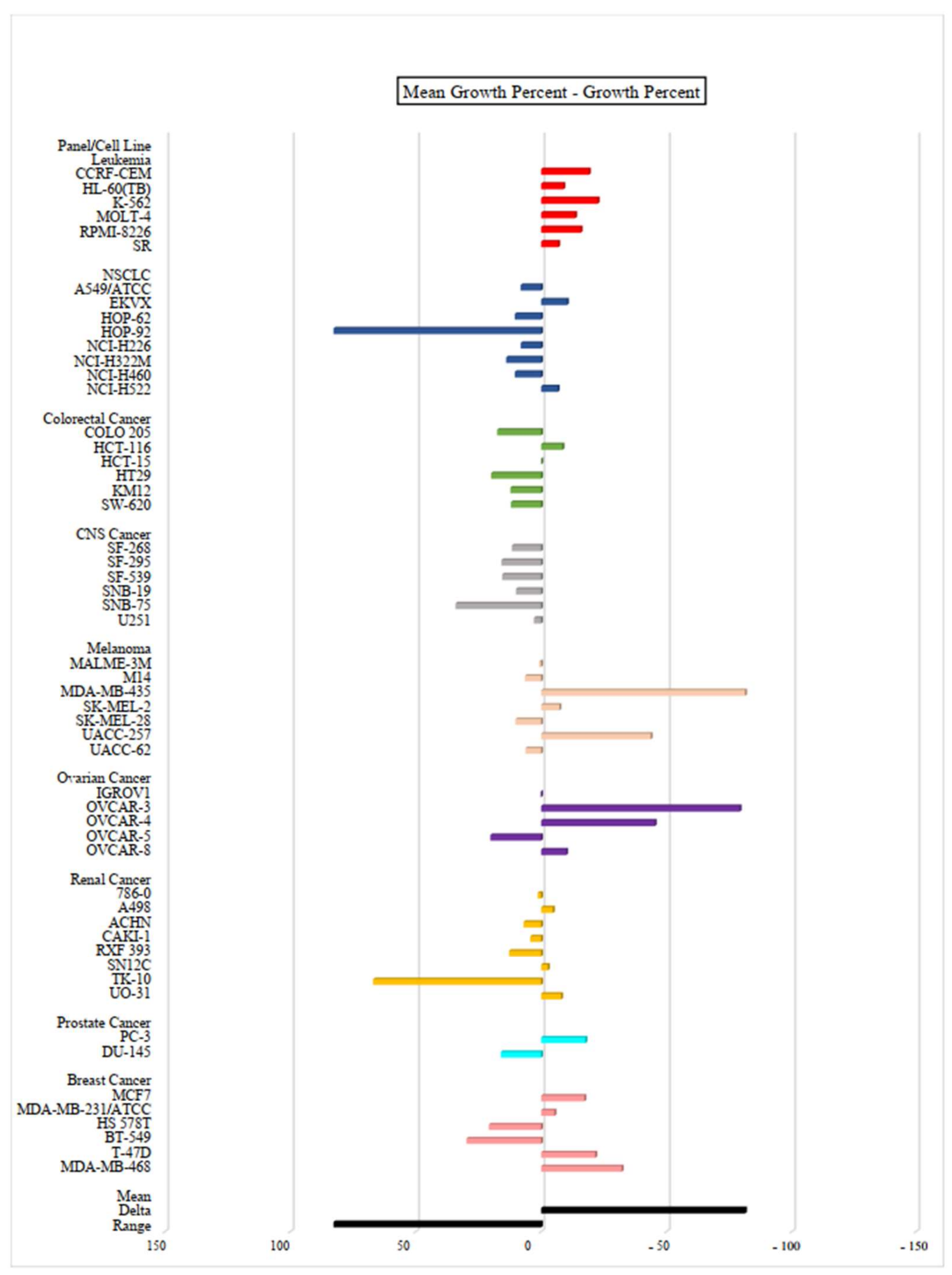

Figure 6. One-dose $(10 \mu \mathrm{M})$ mean graph of PQ3 against different cancer cell lines. All experiments were repeated one time. 


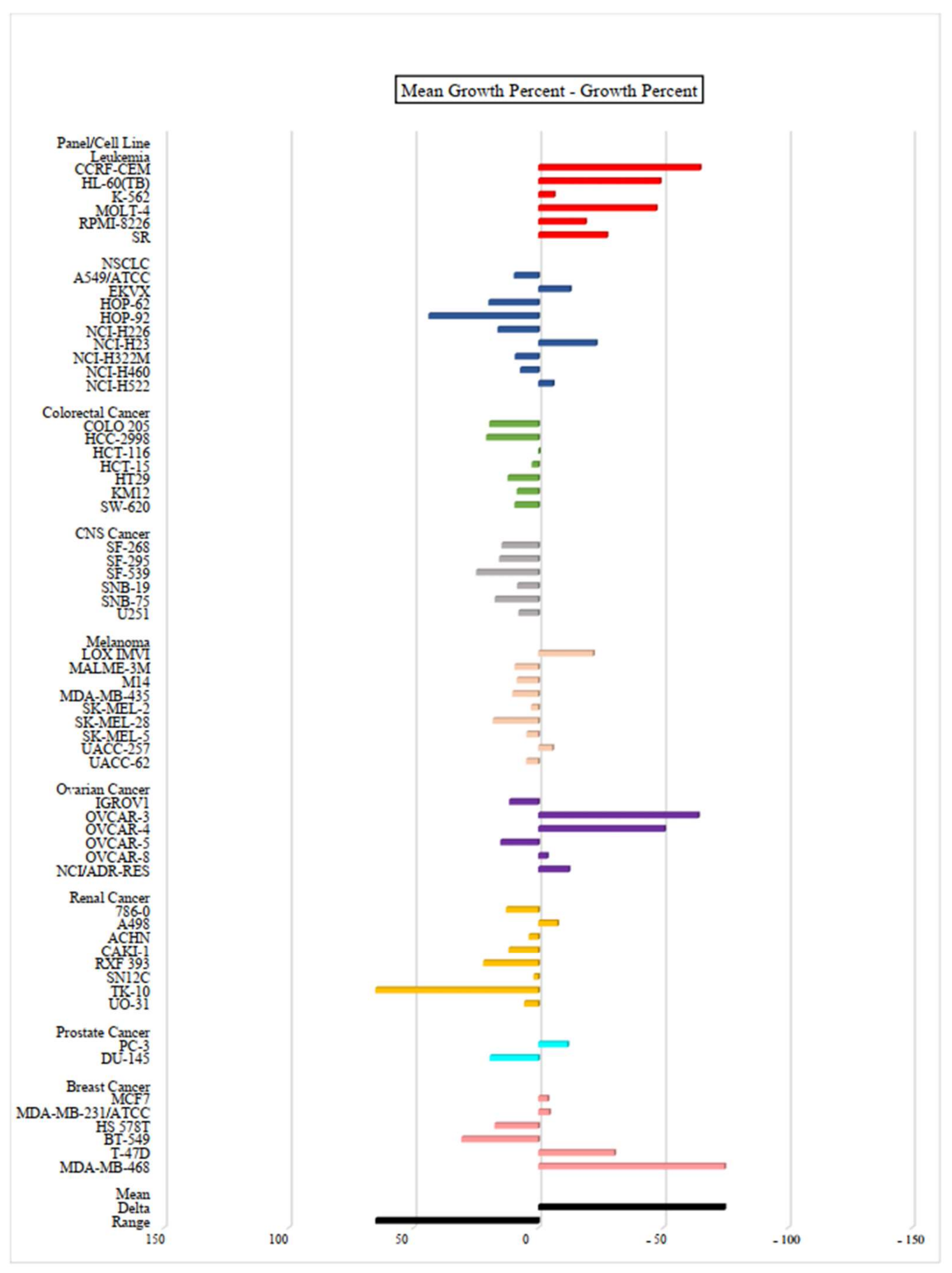

Figure 7. One-dose $(10 \mu \mathrm{M})$ mean graph of PQ10 against different cancer cell lines. All experiments were repeated one time.

\subsubsection{Determination of Cell Viability}

It was determined that antiproliferative effects of PQ2 on HCT-116 cells were found to be more dominant than that of PQ3 and PQ10 compared to other cell lines in the panel of sixty human cancer cell lines. Due to significant inhibitory effects of PQ2 against HCT116 cells at one dose, its cytotoxic effects on HCT-116 cells were also evaluated by MTT 
(3-(4,5-dimethyl-2-thiazolyl)-2,5-diphenyltetrazolium bromide) assay at five concentrations $(1,3,10,30$, and $100 \mu \mathrm{M})$ compared to cisplatin. Cisplatin was chosen as a standard agent due to frequent use in the treatment of colorectal cancer in spite of rapid development of resistance [36].

According to the results, PQ2 exhibited significant cytotoxic effect against HCT116 cells with an $\mathrm{IC}_{50}$ value of $4.97 \pm 1.93 \mu \mathrm{M}$ compared to control drug cisplatin $\left(\mathrm{IC}_{50}=26.65 \pm 7.85 \mu \mathrm{M}\right)(p<0.05)$. Moreover, significant cytotoxic effects of PQ2 on HCT-116 cells at varying concentrations compared to cisplatin are outlined in Figure 8 . The apparent decline in percentage of viable cells was observed between 3 and $10 \mu \mathrm{M}$ with PQ2 treatment, whereas a similar decline appeared between 10 and $30 \mu \mathrm{M}$ with cisplatin treatment.

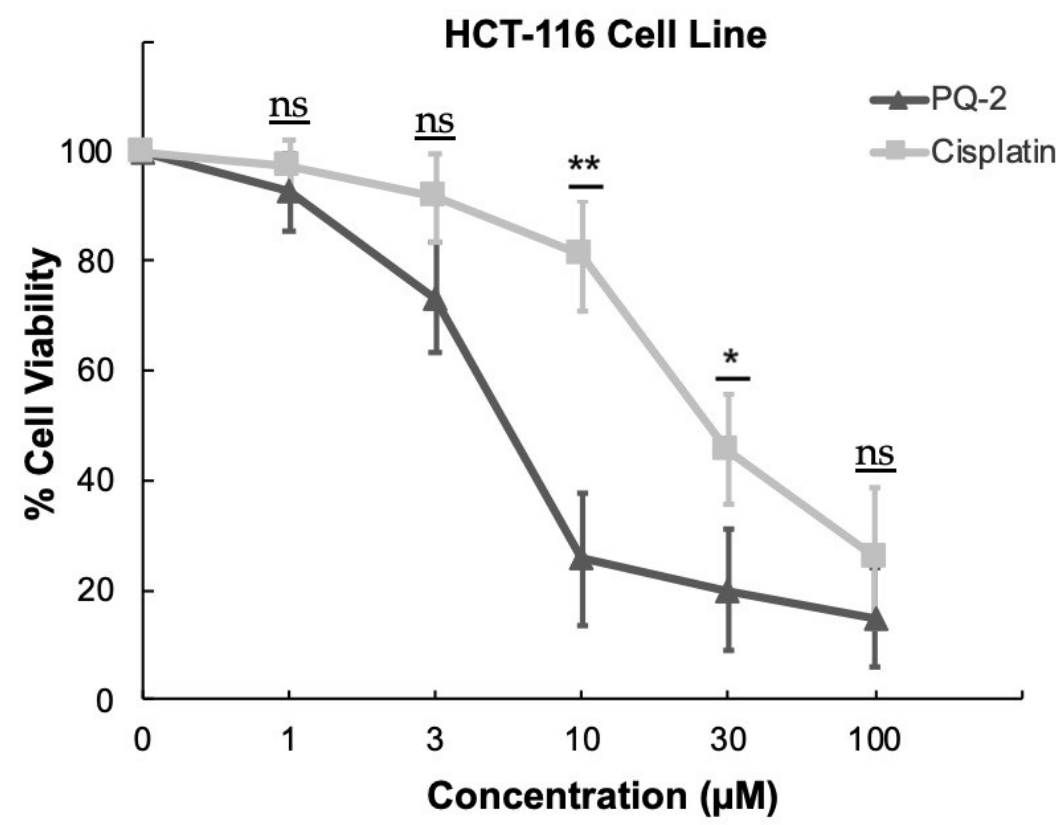

Figure 8. The anticancer effects of PQ2 and cisplatin at varying concentrations on HCT-116 cells. Data are representative of the mean of three separate experiments and are reported at the $\pm \mathrm{SD}$ and $p$ values were determined using Student's $t$ test $\left({ }^{*} p<0.05,{ }^{* *} p<0.01\right.$, ns: not statistically significant).

\subsubsection{Determination of Cell Death}

In the current study, the significant anticancer potential of PQ2 on the HCT-116 cells encouraged us to investigate its apoptotic and necrotic activity in HCT-116 cell line using the annexin V/ethidium homodimer III staining method. This method indicates that apoptotic, necrotic or late apoptotic, and necrotic cells stain positive for green, yellow and red, respectively. These alterations in cells are observed with a fluorescence microscope. It was determined that HCT-116 cells-treated with PQ2 and cisplatin underwent apoptosis mainly in less time (Figure 9A). According to the results, PQ2 revealed 66\% apoptotic, 19\% late apoptotic/necrotic and 15\% necrotic effects when compared with cisplatin $(60 \%, 18 \%$ and 22\%, respectively) at $12 \mathrm{~h}$ (Figure 9B). This outcome pointed out that PQ2 significantly enhanced apoptosis in HCT-116 cells.

It is well-known that there is a correlation between DNA cleavage and apoptosis. It was previously shown that PQ2 was able to cleave DNA in the presence of $\mathrm{FeSO}_{4}, \mathrm{H}_{2} \mathrm{O}_{2}$ and ascorbic acid [29]. Due to significant DNA cleaving activity of PQ2, molecular docking studies were carried out to understand the binding capacity of PQ2 to DNA (PDB ID: 2GWA) in comparison with PQ3 and PQ10 [37]. Results showed that PQ2 displayed higher binding affinity to DNA, forming a hydrogen bond with DT-5 through its methoxy moiety in the minor groove of the double helix of DNA, whereas PQ3 and PQ10 presented no interactions (Figure 10A,B). The docking scores of the compounds were detected to range from -5.628 to $-5.848 \mathrm{kcal} / \mathrm{mol}$ (Table 3 ). 
HCT-116 Cell Line

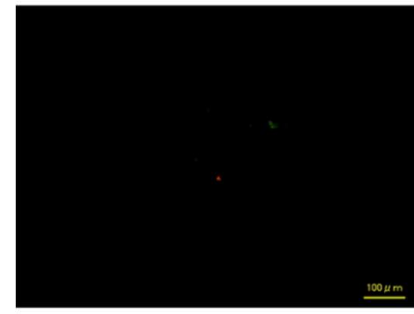

Control

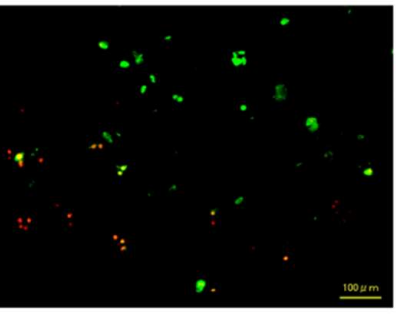

PQ2

(A)

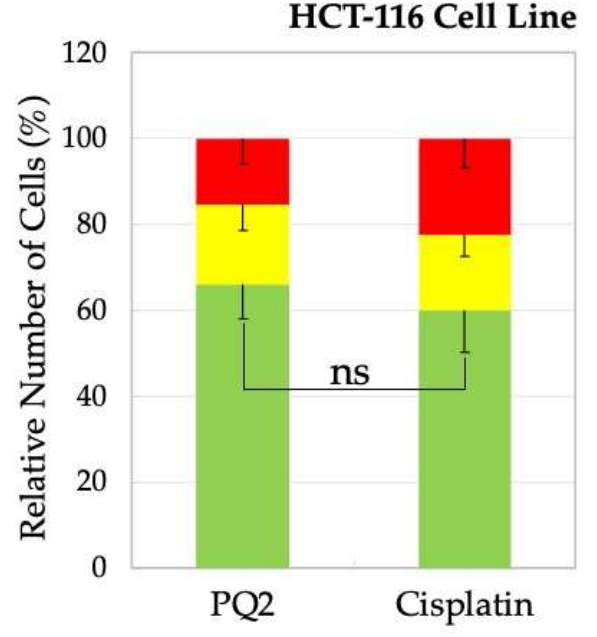

(B)

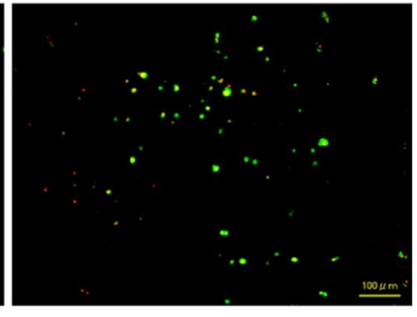

Cisplatin
- Necrosis

Late apoptosis/necrosis

- Apoptosis

Figure 9. Alteration of HCT-116 cells following exposure to the $\mathrm{IC}_{50}$ concentration of the control (DMSO), PQ2, and cisplatin (A) for $12 \mathrm{~h}$. The percentage of apoptotic (green), late apoptotic or necrotic (yellow) and necrotic (red) cells (B) was determined by analyzing 100 randomly chosen stained cells in each experiment. Data from three independent experiments are shown as means $\pm \mathrm{SD}$, and $p$ values were determined using Student's t test (ns: not statistically significant).

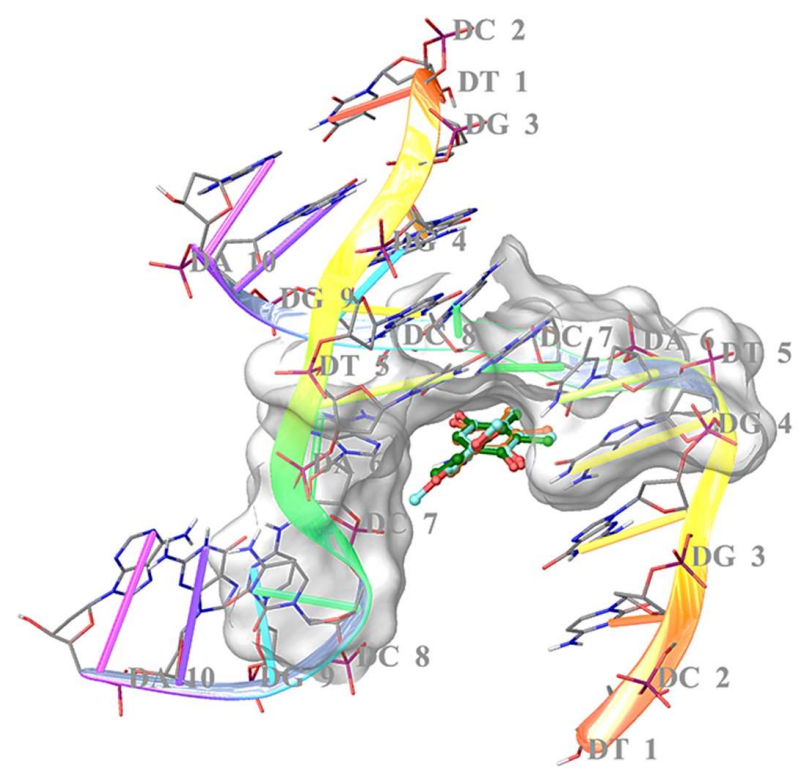

(A)

Figure 10. Cont. 


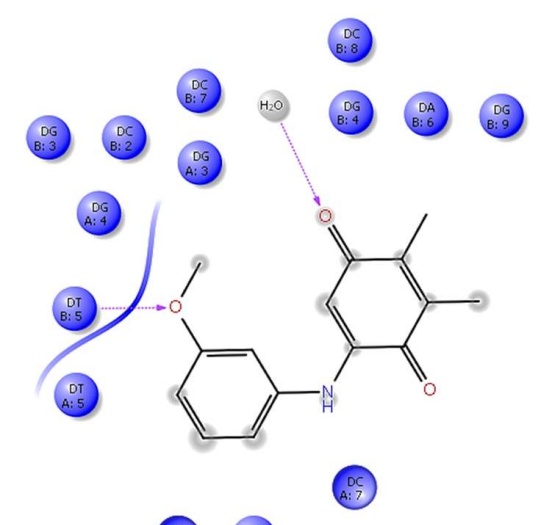

DC $\quad D A$
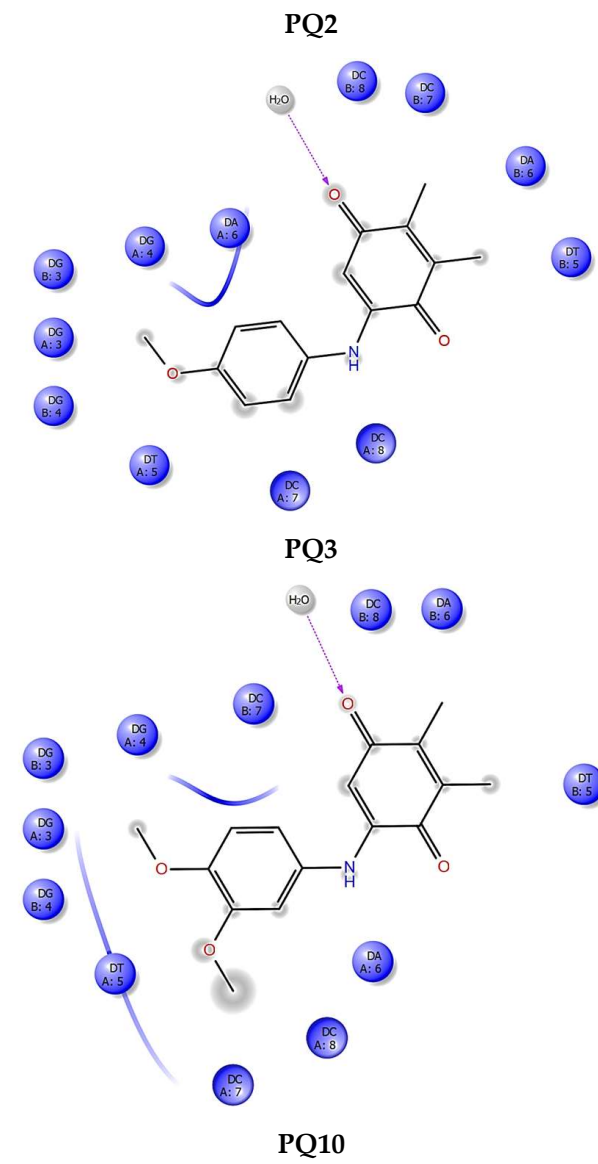

(B)

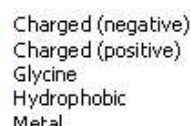
Polar
olar
water
Hydration site
$\times$ Hydration site (displaced)
-.. Distance
$\Rightarrow$ H-bond
- Metal coordination
- Pi-Pi stacking

Metal

$\rightarrow$ Pi-cation

Figure 10. Docking poses (A) and interactions (B) of PQ2, PQ3 and PQ10 (ligands are highlighted in dark green-, orange- and turquoise-colored sticks) in the minor groove of the double helix of DNA (PDB ID: 2GWA). 
Table 3. Docking score $(\mathrm{kcal} / \mathrm{mol})$, glide gscore $(\mathrm{kcal} / \mathrm{mol})$ and glide emodel $(\mathrm{kcal} / \mathrm{mol})$ results of PQ2, PQ3, and PQ10 for DNA (PDB ID: 2GWA).

\begin{tabular}{cccc}
\hline \multirow{2}{*}{ Compound } & \multicolumn{3}{c}{ 2GWA } \\
\cline { 2 - 4 } & Docking Score & Glide Score & Glide Emodel \\
\hline PQ2 & -5.848 & -5.848 & -48.650 \\
PQ3 & -5.628 & -5.628 & -43.682 \\
PQ10 & -5.833 & -5.833 & -44.605 \\
\hline
\end{tabular}

\subsection{In Silico Prediction of Pharmacokinetic Properties}

Some risks and physicochemical properties of PQ2 were estimated by ADMET Predictor 9.0 and compatibility to the Lipinski rule of 5 was confirmed in our previous study [29]. In recent work, some other essential ADME parameters of PQ2 such as predicted octanol/water partition coefficient (QPlogPo/w), predicted aqueous solubility (QPlogS), human serum albumin binding (QPlogKhsa), predicted brain/blood partition coefficient $(\mathrm{QP} \log \mathrm{BB})$ were in silico ascertained.

The QPlogPo/w and the QPlogS values of PQ2 (2.129 and -3.602, respectively) were detected within the range ( -2 to 6.5 and -6.5 to 0.5 , respectively). PQ2 was also found to reveal significant human serum albumin binding with a QPlogKhsa value of -0.133 within the specified range ( -1.5 to 1.5$)$. The QPlogBB value of PQ2 (-0.465) was detected in an optimal range of the specified values ( -3 to 1.2$)$ indicating its ability to cross the blood-brain barrier (BBB). Furthermore, PQ2 presented remarkable human oral absorption $(95.119 \%)$ on a $0-100 \%$ scale $(>80 \%$ is high; $<25 \%$ is poor).

\section{Discussion}

Gastrointestinal cancers are globally responsible for one in three cancer deaths. Within the types of gastrointestinal cancers, colorectal cancer is the third most common type in cases and the second most common type in deaths. In the statistics published by the International Agency for Research on Cancer (IARC) in 2020, about 1.0 million new cases (10.6) in males and 0.8 million new cases in females in all ages were diagnosed with this cancer in the worldwide. Thus, colorectal cancer was slightly more common in males than in females [38].

In previous studies related to the anti-colorectal effects of natural quinone derivatives, significant results were obtained. However, in general the most potent anticancer agents were found to be cytotoxic against healthy cells. Thymoquinone (Figure 11) was searched for its anticancer effects on HT-29 human colorectal adenocarcinoma cells and revealed anticancer activity based on the trypan blue exclusion method [39]. Thymoquinone derivatives were also investigated for their anti-colorectal cancer properties in distinct studies. Thymoquinone- $4 \alpha$-linolenoylhydrazone (TQ-H-10) (Figure 11) and thymoquinone-4palmitoylhydrazone (TQ-H-11) (Figure 11) derivatives were found to be effective towards HCT-116 cells. [40]. In another study [41], 3-aminothymoquinone (ATQ) (Figure 11) was synthesized from starting compound thymoquinone and searched for antiproliferative activity against an SW620 colorectal adenocarcinoma cell line with a WI38 healthy fibroblast cell line. ATQ displayed cytotoxic effects against colorectal cancer cells, whereas this compound also showed cytotoxic affects against WI38 cells. A natural active compound, betulin (Figure 11), is obtained from the bark of white birch trees. 1,4-Quinone-based betulin derivatives were detected to be effective towards different cancer cells including colorectal cancer cells. 1,4-Quinone-based betulin derivatives were synthesized and evaluated for their anticancer effects against seven human cancer cell lines including Caco-2 colorectal cancer cells and HFF1 normal fibroblast cells. 28-(3-(6-chloro-2-methyl-5,8-quinolinedione7-yloxy)-propyl-1H-1,2,3-triazol-4-ynoiloxy)-3-oxolup-20(29)-en (19b) (Figure 11) exhibited the most potent anti-colorectal activity compared to cisplatin, whereas $19 \mathrm{~b}$ also showed cytotoxic effects against HFF1 cells [42]. Recent study showed that PQ2 displayed notable inhibition against HCT-116 cell line though PQ3 and PQ10 showed no cytotoxicity, indicat- 
ing more selective anticancer action of PQ2 towards HCT-116 cells compared to PQ3 and PQ10. This outcome pointed out that the addition of the methoxy substitution to the anilino group led to a decrease in the anticancer activity, as shown in PQ10 compared to PQ2 and PQ3, whereas one methoxy substitution at the meta position on the anilino ring (PQ2) increased anti-colorectal cancer activity when compared with one methoxy substitution at the para position (PQ3). Furthermore, when compared with aforementioned studies, PQ2 revealed superior cytotoxicity against colorectal cancer cells and selective anti-colorectal cancer activity exerting no cytotoxicity to healthy cells.<smiles>C/C=C\C/C=C\C/C=C\CCCCCCCC(=O)N/N=C1\C=C(C(C)C)C(=O)C=C1C</smiles><smiles>CCCCCCCCCCCCCCCC(=O)N/N=C1\C=C(C(C)C)C(=O)C=C1C</smiles>

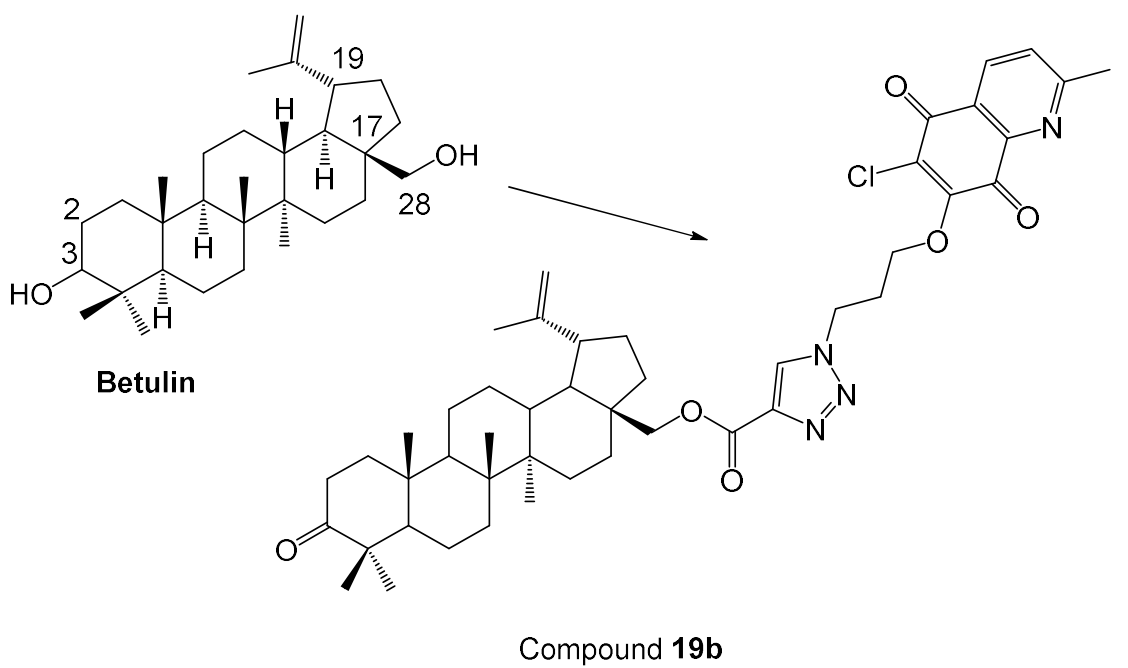

Figure 11. Thymoquinone and betulin analogs as anti-colorectal cancer agents.

Apoptosis is pivotal in tissue homeostasis, particularly in gastrointestinal tract and immune system. In addition, apoptosis induction in cancer cells is a promising strategy for the treatment of cancer. In the early stages of cancer, cancer cells are more sensitive to agents, which stimulate apoptosis. Then, these cells start to become resistant to apoptotic stimuli [43-46]. Therefore, there is an urgent need to discover more potent anticancer agents that also induce apoptosis in cancer cells. Some quinone-based natural compounds were evaluated for their apoptotic effects on colorectal cancer cells. Seetha et al. [21] performed 
morphological analysis, cell cycle regulation, and dual staining using acridine orange and ethidium bromide in control and treated cells revealing the apoptotic potential of juglone (Figure 1) along with indomethacin, which was found to be effective in the proliferation of colorectal cancer cells. The same research group indicated that juglone diminished the inflammatory activity and stimulated apoptosis together with indomethacin [22]. Previously, we also reported that PQ2 demonstrated 69\% apoptotic, 20\% late apoptotic/necrotic, and $11 \%$ necrotic effects on K562 cells at 6 h [29]. This current study pointed out that PQ2 also significantly enhanced apoptosis in colorectal cells when compared with cisplatin.

Molecular docking studies were performed for PQ2 to explore its binding potential in the minor groove of the double helix of DNA. In our previous studies, we also performed molecular docking studies for quinone-based compounds with the most significant DNA cleaving abilities. 7-Chloro-6-(3,5-dimethylphenyl)amino-5,8-quinolinequinone (AQQ15) [47] and 6-(benzo[d][1,3]dioxol-5-ylamino)-7-chloro-5,8-quinolinequinone (AQQ13) [48] formed important interactions with DNA. In the current work, PQ2 also formed a key hydrogen bonding through its methoxy moiety in the minor groove of the double helix of DNA. On the contrary, PQ3 and PQ10 formed no interactions. In general, the docking scores of the compounds were consistent with the biological data. The highest docking score, belonging to PQ2 explained its high binding capacity to DNA. These outcomes indicated that the strong effect of PQ2 against HCT-116 cell line would be related to strong DNA binding of PQ2. Moreover, it can be concluded that the presence of a methoxy substituent at third position of anilino ring played a fundamental role in binding with DNA when compared with 4-methoxyanilino and 3,4-dimethoxyanilino substituted compounds (PQ3 and PQ10, respectively).

The $\log \mathrm{Po} / \mathrm{w}$ is a crucial pharmacokinetic determinant, which affects membrane permeability, metabolism, binding potency to the target, bioavailability and toxicity of compounds [49]. In order to show its physiological effect, compounds should also transport to the site of action in particular in aqueous environments as the human body consists of approximately $60 \%$ water. Furthermore, compounds with low aqueous solubility are prone to demonstrate poor uptake, lack of pharmacological effect, manufacturing and storage problems [50]. Moreover, the determination of QPlogKhsa acts a crucial role for a suitable pharmacokinetic profile of compounds at an acceptable dose and dose frequency influencing volume of distribution and half-life of them [51]. The BBB restrains drug entry from blood into brain by multiple mechanisms [52]. The QPlogPo/w, the QPlogS, the QPlogKhsa and the QPlogBB values of PQ2 were detected in an optimal range of the specified values with a high human oral absorption percentage indicating that PQ2 possessed orally bioavailable drug-like properties.

\section{Materials and Methods}

\subsection{Chemistry}

The synthetic protocol and spectral data of PQ2, PQ3, and PQ10 were reported previously [29].

\subsection{Biological Evaluation}

\subsubsection{In Vitro Antiproliferative Activity at Single-Dose Concentration by NCI}

PQ analogs were submitted to NCI, Bethesda, USA and, as per standard protocol of NCI, all compounds were evaluated for their antiproliferative activity at single dose assay (10 $\mu \mathrm{M}$ concentration in DMSO) on a panel of sixty cancer cell lines derived from leukemia, lung, colorectal, CNS, melanoma, ovarian, renal, prostate, and breast cancers as per protocol [43]. Tested compounds were added to the microtiter culture plates followed by incubation for $48 \mathrm{~h}$ at $37^{\circ} \mathrm{C}$. SRB, a protein binding dye, was used for end point determination. The percent of growth of the treated cells was determined in comparison to the untreated control cells and the results of each tested compound were reported. Data from one-dose experiments pertain to the percentage growth at $10 \mu \mathrm{M}[53,54]$. 


\subsubsection{Cell Culture and Drug Treatment}

The HCT-116 cell line (provided by the RIKEN BRC through the National Bio-Resource Project of the MEXT/AMED, Japan (RCB2979)) was incubated in Dulbecco's modified Eagle's medium (DMEM) (Wako Pure Chemical Industries, Osaka, Japan). DMEM was supplemented with 10\% fetal bovine serum (FBS) (Sigma Aldrich, St. Louis, MO, USA) and $89 \mu \mathrm{g} / \mathrm{mL}$ streptomycin (Meiji Seika Pharma, Tokyo, Japan) at $37^{\circ} \mathrm{C}$ in humidified $5 \% \mathrm{CO}_{2}$ atmosphere. HCT-116 cells were cultured in 24-well plate (Iwaki brand Asahi Glass Co., Chiba, Japan) at $4 \times 10^{4}$ cells $/ \mathrm{mL}$ concentration for $48 \mathrm{~h}$ (the optimum cell number was verified associated with previous study) [55]. The stock solution of PQ2 and cisplatin in concentrations ranging from 0.1 to $10 \mathrm{mM}$ were prepared in DMSO (Wako Pure Chemical Industries, Osaka, Japan) and further diluted with fresh culture medium. The concentration of DMSO in the final culture medium was $1 \%$ which had no effect on the cell viability.

\subsubsection{MTT Assay}

MTT (Dojindo Molecular Technologies, Kumamoto, Japan) was used to determine the effects of PQ2 and cisplatin on cell viability as previously described [56,57]. HCT116 cells were treated with PQ2 and cisplatin at five concentrations $(1,3,10,30$, and $100 \mu \mathrm{M})$ for $48 \mathrm{~h}$ at $37^{\circ} \mathrm{C}$ and then stained with MTT solution and further incubated for $4 \mathrm{~h}$. Afterwards, supernatants were removed and $100 \mu \mathrm{L}$ DMSO was added to each well. The absorbance of the solution was analyzed using a plate reader Infinite M1000 (Tecan, Mannedorf, Switzerland). All experiments were carried out as three times and $\mathrm{IC}_{50}$ values were determined as the drug concentrations that decreased absorbance to $50 \%$ of control values.

\subsubsection{Detection of Cell Death}

The HCT-116 cell line was incubated with PQ2 and cisplatin at $\mathrm{IC}_{50}$ concentration for $12 \mathrm{~h}$ before the apoptotic/necrotic/detection kit (PromoKine, Heidelberg, Germany) was applied with some modifications to the manufacturer's directions [55,58]. Then, HCT-116 cells, which were treated with appropriate content including binding buffer and staining solution, were detected by an all-in-one fluorescence microscope Biorevo Fluorescence BZ-9000 (Keyence, Osaka, Japan). Based on our previous studies [59], the number of apoptotic, late apoptotic or necrotic and necrotic cells was counted relevant to the staining with annexin $\mathrm{V}$ and ethidium homodimer III.

\subsection{Molecular Docking Studies}

PQ2 was sketched and cleaned in the Maestro molecular modeling workspace followed by energy minimization in the ligand preparation program of Schrödinger's Maestro molecular modeling package (Schrödinger Release 2016-2: Schrödinger, LLC, New York, NY, USA) using an Optimized Potential Liquid Simulations (OPLS_2005) force field at physiological $\mathrm{pH}(\mathrm{pH}=7.4)$. The $\mathrm{X}$-ray crystallographic structure of DNA was acquired from the PDB server (PDB ID: 2GWA) [37] and optimized for docking analysis in protein preparation module of Schrödinger software. In molecular docking simulations, Grid Generation and Glide/ XP docking protocols were implemented [47,48].

\subsection{In Silico ADME Estimation}

Some pharmacokinetic characteristics of PQ2 were calculated by the QikProp module of Schrödinger software (Schrödinger Release 2016-2: QikProp, Schrödinger, LLC, New York, NY, USA, 2016) [47,48].

\section{Conclusions}

The potential cytotoxic effects of a series of $\mathbf{P Q}$ analogs bearing alkoxy substituted anilino moiety were previously heralded by our research team. Among these analogs, PQ2, PQ3 and PQ10 were chosen by NCI for in vitro screening of antiproliferative activity against a wide range of cancer cell lines stemming from nine distinct cancer types. The 
3-Methoxyphenyl carrying compound (PQ2) exerted superior antiproliferative activity against the HCT-116 cell line compared to PQ3 and PQ10. The results of MTT assay also supported the promising anti-colorectal cancer effects of PQ2 at different concentrations. Further studies also indicated that PQ2 induced apoptosis in colorectal cancer cells compared to cisplatin and it was found to establish proper hydrogen bonding with DNA reinforcing the DNA cleavage-associated cell death. Some in silico predicted ADME parameters reflected that $\mathbf{P Q 2}$ was endowed with orally bioavailable drug-like properties. All these outcomes shed light on future mechanistic studies for PQ2 owing to its notable anticancer activity against colorectal cancer. To the best of our knowledge, one of the more significant findings to emerge from this study is that this is the first study showing the anti-colorectal cancer activity of $\mathbf{P Q}$ analogs. This finding has important implications for developing new agents based on PQ for colorectal cancer treatment instead of the known inhibitors.

Author Contributions: Conceptualization, H.C., B.S., M.F. and A.F.T.; methodology, H.C., B.S., N.B., M.Y., H.Y. and A.F.T.; software, H.C., B.S. and F.O.; validation, H.C., B.S. and F.O.; formal analysis, H.C. and B.S.; investigation, H.C., B.S., N.B., M.Y., H.Y. and A.F.T.; resources, H.T., M.O. and M.F.; data curation, H.C.; writing-original draft preparation, H.C., B.S. and A.F.T.; writing-review and editing, H.C., B.S., F.O., N.B., M.Y., H.D., H.Y., H.T., M.O., M.F. and A.F.T.; visualization, H.C., B.S. and F.O.; supervision, M.F. and A.F.T.; project administration, M.F. and A.F.T.; funding acquisition, A.F.T. All authors have read and agreed to the published version of the manuscript.

Funding: This work was financially supported by the Scientific Research Projects Coordination Unit of Istanbul University-Cerrahpasa (Project number: FBA-2017-24559) for supplying the equipment and materials. This publication has been produced benefiting from TUBITAK 2236 CoCirculation2, grant number $12 \mathrm{C} 063$. However, the entire responsibility of the publication belongs to the authors. The financial support received from TUBITAK does not mean that the content of the publication is approved in a scientific sense by TUBITAK.

Institutional Review Board Statement: Not applicable.

Informed Consent Statement: Not applicable.

Data Availability Statement: Not applicable.

Acknowledgments: The authors present their thanks to the National Cancer Institute (NCI), Bethesda, MD, USA for carrying out the anticancer activity by the Developmental Therapeutics Program (DTP), Division of Cancer Treatment and Diagnosis, National Cancer Institute (http://dtp.cancer.gov, accessed on 21 October 2020). The HCT-116 was provided by the RIKEN BRC.

Conflicts of Interest: The authors declare no conflict of interest.

Sample Availability: Samples of the compounds PQ2, PQ3, and PQ10 are available from the authors.

\section{References}

1. Brannon-Peppas, L.; Blanchette, J.O. Nanoparticle and targeted systems for cancer therapy. Adv. Drug Deliv. Rev. 2004, 56, 1649-1659. [CrossRef] [PubMed]

2. Hebar, A.; Valent, P.; Selzer, E. The impact of molecular targets in cancer drug development: Major hurdles and future strategies. Expert Rev. Clin. Pharmacol. 2013, 6, 23-34. [CrossRef] [PubMed]

3. Gewirtz, D.A.; Bristol, M.L.; Yalowich, J.C. Toxicity issues in cancer drug development. Curr. Opin. Investig. Drugs 2010, 11, 612-614. [PubMed]

4. Cragg, G.M.; Grothaus, P.G.; Newman, D.J. Impact of natural products on developing new anti-cancer agents. Chem. Rev. 2009, 109, 3012-3043. [CrossRef] [PubMed]

5. Newman, D.J.; Cragg, G.M. Natural products as sources of new drugs over the last 25 years. J. Nat. Prod. 2007, 70, 461-477. [CrossRef] [PubMed]

6. Butler, M.S. Natural products to drugs: Natural product-derived compounds in clinical trials. Nat. Prod. Rep. 2008, 25, 475-516. [CrossRef]

7. Collett, N.P.; Amin, A.R.M.R.; Bayraktar, S.; Pezzuto, J.M.; Shin, D.M.; Khuri, F.R.; Aggarwal, B.B.; Surh, Y.J.; Kucuk, O. Cancer prevention with natural compounds. Semin. Oncol. 2010, 37, 258-281.

8. Begleiter, A. Clinical applications of quinone-containing alkylating agents. Front. Biosci. 2000, 5, E153-E171. [CrossRef]

9. Newman, D.J.; Cragg, G.M. Natural products as sources of new drugs from 1981 to 2014. J. Nat. Prod. 2016, 79, 629-661. [CrossRef] 
10. de Almeida, P.D.O.; Jobim, G.D.B.; Ferreira, C.C.D.; Bernardes, L.R.; Dias, R.B.; Sales, C.B.S.; Valverde, L.D.; Rocha, C.A.G.; Soares, M.B.P.; Bezerra, D.P.; et al. A new synthetic antitumor naphthoquinone induces ROS-mediated apoptosis with activation of the JNK and p38 signaling pathways. Chem. Biol. Interact. 2021, 343, 109444. [CrossRef]

11. Wellington, K.W.; Kolesnikova, N.I.; Nyoka, N.B.P.; McGaw, L.J. Investigation of the antimicrobial and anticancer activity of aminonaphthoquinones. Drug Dev. Res. 2019, 80, 138-146. [CrossRef]

12. Wellington, K.W. Understanding cancer and the anticancer activities of naphthoquinones-A review. RSC Adv. 2015, 5, 20309-20338. [CrossRef]

13. Defant, A.; Mancini, I. Design, synthesis and cancer cell growth inhibition evaluation of new aminoquinone hybrid molecules. Molecules 2019, 24, 2224. [CrossRef] [PubMed]

14. Nain-Perez, A.; Barbosa, L.C.A.; Rodriguez-Hernandez, D.; Kramell, A.E.; Heller, L.; Csuk, R. Natural abenquines and synthetic analogues: Preliminary exploration of their cytotoxic activity. Bioorg. Med. Chem. Lett. 2017, 27, 1141-1144. [CrossRef] [PubMed]

15. Aminin, D.; Polonik, S. 1,4-Naphthoquinones: Some biological properties and application. Chem. Pharmacol. Bull. 2020, 68, 46-57. [CrossRef] [PubMed]

16. Kruschel, R.D.; Buzid, A.; Khandavilli, U.B.R.; Lawrence, S.E.; Glennon, J.D.; McCarthy, F.O. Isoquinolinequinone N-oxides as anticancer agents effective against drug resistant cell lines. Org. Biomol. Chem. 2020, 18, 557-568. [CrossRef] [PubMed]

17. Coutelle, O.; Hornig-Do, H.T.; Witt, A.; Andree, M.; Schiffmann, L.M.; Piekarek, M.; Brinkmann, K.; Seeger, J.M.; Liwschitz, M.; Miwa, S.; et al. Embelin inhibits endothelial mitochondrial respiration and impairs neoangiogenesis during tumor growth and wound healing. EMBO Mol. Med. 2014, 6, 624-639. [CrossRef]

18. Asaduzzaman Khan, M.A.; Tania, M.; Fu, S.Y.; Fu, J.J. Thymoquinone, as an anticancer molecule: From basic research to clinical investigation. Oncotarget 2017, 8, 51907-51919. [CrossRef]

19. Mostofa, A.G.M.; Hossain, M.K.; Basak, D.; Bin Sayeed, M.S. Thymoquinone as a potential adjuvant therapy for cancer treatment: Evidence from preclinical studies. Front. Pharmacol. 2017, 8, 295. [CrossRef]

20. Wang, H.; Zou, C.; Zhao, W.; Yu, Y.; Cui, Y.; Zhang, H.E.F.; Qiu, Z.; Zou, C.; Gao, X. Juglone eliminates MDSCs accumulation and enhances antitumor immunity. Int. Immunopharmacol. 2019, 73, 118-127. [CrossRef]

21. Seetha, A.; Devaraj, H.; Sudhandiran, G. Indomethacin and juglone inhibit inflammatory molecules to induce apoptosis in colon cancer cells. J. Biochem. Mol. Toxicol. 2020, 34, e22433. [CrossRef]

22. Seetha, A.; Devaraj, H.; Sudhandiran, G. Effects of combined treatment with indomethacin and juglone on AOM/DSS induced colon carcinogenesis in Balb/c mice: Roles of inflammation and apoptosis. Life Sci. 2021, 264, 118657. [CrossRef] [PubMed]

23. Majiene, D.; Kuseliauskyte, J.; Stimbirys, A.; Jekabsone, A. Comparison of the effect of native 1,4-naphthoquinones plumbagin, menadione, and lawsone on viability, redox status, and mitochondrial functions of C6 glioblastoma cells. Nutrients 2019, 11, 1294. [CrossRef]

24. Kawamukai, M. Biosynthesis and applications of prenylquinones. Biosci. Biotechnol. Biochem. 2018, 82, 963-977. [CrossRef] [PubMed]

25. Boler, J.; Pardini, R.; Mustafa, H.T.; Folkers, K.; Dilley, R.A.; Crane, F.L. Synthesis of plastoquinone analogs and inhibition of photosynthetic and mammalian enzyme systems. Proc. Natl. Acad. Sci. USA 1972, 69, 3713-3717. [CrossRef] [PubMed]

26. Liu, M.M.; Lu, S.F. Plastoquinone and ubiquinone in plants: Biosynthesis, physiological function and metabolic engineering. Front. Plant Sci. 2016, 7, 1898. [CrossRef]

27. Jannuzzi, A.T.; Yıldız, M.; Bayrak, N.; Yıldırım, H.; Shilkar, D.; Jayaprakash, V.; Tuyun, A.F. Anticancer agents based on Plastoquinone analogs with $N$-phenylpiperazine: Structure-activity relationship and mechanism of action in breast cancer cells. Chem. Biol. Interact. 2021, 349, 109673. [CrossRef]

28. Bayrak, N.; Yildirim, H.; Yildiz, M.; Radwan, M.O.; Otsuka, M.; Fujita, M.; Ciftci, H.I.; Tuyun, A.F. A novel series of chlorinated plastoquinone analogs: Design, synthesis, and evaluation of anticancer activity. Chem. Biol. Drug Des. 2020, 95, 343-354. [CrossRef]

29. Bayrak, N.; Yildirim, H.; Yildiz, M.; Radwan, M.O.; Otsuka, M.; Fujita, M.; Tuyun, A.F.; Ciftci, H.I. Design, synthesis, and biological activity of Plastoquinone analogs as a new class of anticancer agents. Bioorg. Chem. 2019, 92, 103255. [CrossRef]

30. Ciftci, H.I.; Bayrak, N.; Yildirim, H.; Yildiz, M.; Radwan, M.O.; Otsuka, M.; Fujita, M.; Tuyun, A.F. Discovery and structure-activity relationship of plastoquinone analogs as anticancer agents against chronic myelogenous leukemia cells. Arch. Pharmacol. 2019, 352, 1900170. [CrossRef]

31. Yildirim, H.; Bayrak, N.; Yildiz, M.; Kara, E.M.; Celik, B.O.; Tuyun, A.F. Thiolated plastoquinone analogs: Synthesis, characterization, and antimicrobial evaluation. J. Mol. Struct. 2019, 1195, 681-688. [CrossRef]

32. Yildirim, H.; Bayrak, N.; Tuyun, A.F.; Kara, E.M.; Celik, B.O.; Gupta, G.K. 2,3-Disubstituted-1,4-naphthoquinones containing an arylamine with trifluoromethyl group: Synthesis, biological evaluation, and computational study. RSC Adv. 2017, 7, 25753-25764. [CrossRef]

33. Ibis, C.; Ozsoy-Gunes, Z.; Tuyun, A.F.; Ayla, S.S.; Bahar, H.; Stasevych, M.V.; Musyanovych, R.Y.; Komarovska-Porokhnyavets, O.; Novikov, V. Synthesis, antibacterial and antifungal evaluation of thio- or piperazinyl-substituted 1,4-naphthoquinone derivatives. J. Sulfur Chem. 2016, 37, 477-487. [CrossRef]

34. Tuyun, A.F.; Bayrak, N.; Yildirim, H.; Onul, N.; Kara, E.M.; Celik, B.O. Synthesis and in vitro biological evaluation of aminonaphthoquinones and benzo[b]phenazine-6,11-dione derivatives as potential antibacterial and antifungal compounds. J. Chem. 2015, 2015, 645902. [CrossRef] 
35. Boyd, M.R.; Pauli, K.D. Some practical considerations and applications of the National-Cancer-Institute in vitro anticancer drug discovery screen. Drug Dev. Res. 1995, 34, 91-109. [CrossRef]

36. Yin, A.; Jiang, Y.; Zhang, X.; Zhao, J.; Luo, H. Transfection of PDCD5 sensitizes colorectal cancer cells to cisplatin-induced apoptosis in vitro and in vivo. Eur. J. Pharmacol. 2010, 649, 120-126. [CrossRef]

37. Brogden, A.L.; Hopcroft, N.H.; Searcey, M.; Cardin, C.J. Ligand bridging of the DNA Holliday junction: Molecular recognition of a stacked-X four-way junction by a small molecule. Angew. Chem. Int. Ed. Eng. 2007, 46, 3850-3854. [CrossRef]

38. Colorectal Cancer. Available online: https://gco.iarc.fr/today/data/factsheets/cancers/10_8_9-Colorectum-fact-sheet.pdf (accessed on 19 October 2021).

39. Khalife, R.; Hodroj, M.H.; Fakhoury, R.; Rizk, S. Thymoquinone from Nigella sativa seeds promotes the antitumor activity of noncytotoxic doses of topotecan in human colorectal cancer cells in vitro. Planta Med. 2016, 82, 312-321. [CrossRef] [PubMed]

40. Wirries, A.; Breyer, S.; Quint, K.; Schobert, R.; Ocker, M. Thymoquinone hydrazone derivatives cause cell cycle arrest in p53-competent colorectal cancer cells. Exp. Ther. Med. 2010, 1, 369-375. [CrossRef] [PubMed]

41. Glamočlija, U.; Padhye, S.; Špirtović-Halilović, S.; Osmanović, A.; Veljović, E.; Roca, S.; Novaković, I.; Mandić, B.; Turel, I.; Kljun, J.; et al. Synthesis, biological evaluation and docking studies of benzoxazoles derived from thymoquinone. Molecules 2018, 23, 3297. [CrossRef] [PubMed]

42. Kadela-Tomanek, M.; Jastrzebska, M.; Marciniec, K.; Chrobak, E.; Bebenek, E.; Latocha, M.; Kusmierz, D.; Boryczka, S. Design, synthesis and biological activity of 1,4-quinone moiety attached to betulin derivatives as potent DT-diaphorase substrate. Bioorg. Chem. 2021, 106, 104478. [CrossRef] [PubMed]

43. Mohammad, R.M.; Muqbil, I.; Lowe, L.; Yedjou, C.; Hsu, H.Y.; Lin, L.T.; Siegelin, M.D.; Fimognari, C.; Kumar, N.B.; Dou, Q.P.; et al. Broad targeting of resistance to apoptosis in cancer. Semin. Cancer Biol. 2015, 35, S78-S103. [CrossRef]

44. Jia, L.T.; Chen, S.Y.; Yang, A.G. Cancer gene therapy targeting cellular apoptosis machinery. Cancer Treat. Rev. 2012, 38, 868-876. [CrossRef] [PubMed]

45. Kruyt, F.A.; Schuringa, J.J. Apoptosis and cancer stem cells: Implications for apoptosis targeted therapy. Biochem. Pharmacol. 2010, 80, 423-430. [CrossRef]

46. Bold, R.J.; Termuhlen, P.M.; McConkey, D.J. Apoptosis, cancer and cancer therapy. Surg. Oncol. 1997, 6, 133-142. [CrossRef]

47. Bayrak, N.; Ciftci, H.I.; Yildiz, M.; Yildirim, H.; Sever, B.; Tateishi, H.; Otsuka, M.; Fujita, M.; Tuyun, A.F. Structure based design, synthesis, and evaluation of anti-CML activity of the quinolinequinones as LY83583 analogs. Chem. Biol. Interact. 2021, $345,109555$. [CrossRef]

48. Ciftci, H.I.; Bayrak, N.; Yıldız, M.; Yıldırım, H.; Sever, B.; Tateishi, H.; Otsuka, M.; Fujita, M.; Tuyun, A.F. Design, synthesis and investigation of the mechanism of action underlying anti-leukemic effects of the quinolinequinones as LY83583 analogs. Bioorg. Chem. 2021, 114, 105160. [CrossRef]

49. Kim, T.; Park, H. Computational prediction of octanol-water partition coefficient based on the extended solvent-contact model. J. Mol. Graph. Model. 2015, 60, 108-117. [CrossRef]

50. Hewitt, M.; Cronin, M.T.; Enoch, S.J.; Madden, J.C.; Roberts, D.W.; Dearden, J.C. In silico prediction of aqueous solubility: The solubility challenge. J. Chem. Inf. Model. 2009, 49, 2572-2587. [CrossRef]

51. Vallianatou, T.; Lambrinidis, G.; Tsantili-Kakoulidou, A. In silico prediction of human serum albumin binding for drug leads. Expert Opin. Drug Discov. 2013, 8, 583-595. [CrossRef]

52. Pardridge, W.M. Drug and gene delivery to the brain: The vascular route. Neuron 2002, 36, 555-558. [CrossRef]

53. Monks, A.; Scudiero, D.; Skehan, P.; Shoemaker, R.; Paull, K.; Vistica, D.; Hose, C.; Langley, J.; Cronise, P.; Vaigrowolff, A.; et al. Feasibility of a high-flux anticancer drug screen using a diverse panel of cultured human tumor cell lines. J. Natl. Cancer Inst. 1991, 83, 757-766. [CrossRef] [PubMed]

54. Grever, M.R.; Schepartz, S.A.; Chabner, B.A. The National-Cancer-Institute: Cancer drug discovery and development program. Semin. Oncol. 1992, 19, 622-638. [PubMed]

55. Sever, B.; Altintop, M.D.; Ozdemir, A.; Akalin Ciftci, G.; Ellakwa, D.E.; Tateishi, H.; Radwan, M.O.; Ibrahim, M.A.A.; Otsuka, M.; Fujita, M.; et al. In vitro and in silico evaluation of anticancer activity of new indole-based 1,3,4-oxadiazoles as EGFR and COX-2 inhibitors. Molecules 2020, 25, 5190. [CrossRef]

56. Ciftci, H.I.; Radwan, M.O.; Sever, B.; Hamdy, A.K.; Emirdağ, S.; Ulusoy, N.G.; Sozer, E.; Can, M.; Yayli, N.; Araki, N.; et al. EGFR-targeted pentacyclic triterpene analogues for glioma therapy. Int. J. Mol. Sci. 2021, 22, 10945. [CrossRef]

57. Zeytün, E.; Altıntop, M.D.; Sever, B.; Özdemir, A.; Ellakwa, D.E.; Ocak, Z.; Ciftci, H.I.; Otsuka, M.; Fujita, M.; Radwan, M.O. A new series of antileukemic agents: Design, synthesis, in vitro and in silico evaluation of thiazole-based ABL1 kinase inhibitors. Anticancer Agents Med. Chem. 2021, 21, 1099-1109. [CrossRef]

58. Ciftci, H.I.; Can, M.; Ellakwa, D.E.; Suner, S.C.; Ibrahim, M.A.; Oral, A.; Sekeroglu, N.; Özalp, B.; Otsuka, M.; Fujita, M.; et al. Anticancer activity of Turkish marine extracts: A purple sponge extract induces apoptosis with multitarget kinase inhibition activity. Investig. New Drugs 2020, 38, 1326-1333. [CrossRef]

59. Tateishi, H.; Monde, K.; Anraku, K.; Koga, R.; Hayashi, Y.; Ciftci, H.I.; DeMirci, H.; Higashi, T.; Motoyama, K.; Arima, H.; et al. A clue to unprecedented strategy to HIV eradication: "Lock-in and apoptosis". Sci. Rep. 2017, 7, 8957. [CrossRef] [PubMed] 